\title{
Analysis of the of Propellants-Polymers Compatibility by Different Test Methods
}

\author{
Mirjana Dimić ${ }^{1)}$ \\ Bojana Fidanovski ${ }^{1)}$ \\ Ljiljana Jelisavac $^{1)}$ \\ Vesna Rodić ${ }^{1)}$
}

\begin{abstract}
This paper shows the results of chemical compatibility of two types of propellants (NGB-051and NC-28) with two types of polymer materials (Polyamide 12 and Polymethylmetacrylate) by different test methods. Testing was performed using heat flow calorimetry, differential scanning calorimetry, the method of chemical analysis after aging and vacuum stability test method according to STANAG 4147. The heat flow curves of propellants, polymeric materials and their mixtures and the theoretical curves were determined. Produced energy was calculated and the values of relative and absolute compatibility were determined. Analysis of the exothermic peak of decomposition of propellants and its mixture with polymer materials was performed and the maximum difference in peak temperatures was calculated. The stabilizer content of the unheated propellants, the artificially aged propellants and the propellants after heating in contact with the polymer material was determined. The values of the volume of released gas, by using vacuum stability test method, for the propellants and polymer materials as well as their mixtures were determined. The value of absolute compatibility was calculated. Compatibility was estimated on the basis of the results presented.
\end{abstract}

Key words: single base propellant, double base propellant, polymer materials, compatibility, test method, heat flow calorimetry, differential sacnning calorimetry, aging, stability analysis.

\section{Used symbols}

STANAG_Standardisation Agreement of NATO/PfP.

DSC_-differential scanning calorimeter

TGA - thermogravimetry analysis

DTA _ differential thermal analysis

HFC - Heat Flow Microcalorimetry

NGB - Nitroglycerin

NC - Nitrocellulose

PMMA -Polymethylmethacrylate

Nylon 12 -Polyamide 12

SORS - Standard of Defense of the Republic of Serbia

\section{Introduction}

$\mathrm{E}^{\mathrm{N}}$ NERGETIC materials, such as pyrotechnics, explosives and propellants, are thermodynamically unstable highenergy materials. Their characteristics such as functionality and safety are changed during aging. Most of propellants are subjected to slight chemical decomposition already at room temperature. This process entails a number of mechanisms and chemical decomposition reactions, many of which are self-accelerated [1].

Energetic materials are in contact with a large number of materials such as plastics, adhesives, waxes and metals, either by direct contact or through the environment within the ammunition. The compatibility of energetic materials with other components used in ammunition is extremely important having in mind high demands regarding their safety and functioning. The ideal case of compatibility would be no reaction between materials even after long storage periods in various conditions. For practical reasons, materials are considered as compatible if during and after a specified storage period the functioning and safety of the components are still acceptable [2].

Comparing to chemical aging reactions, incompatibility of energetic materials is much less investigated. However, aging of energetic materials is related to incompatibility. Incompatibility can either accelerate the 'normal' ageing reactions or even activate new. As a consequence, stability and compatibility of energetic materials have to be thoroughly investigated before the energetic materials can be safely manufactured, stored and used in technical applications [3].

In general, the most important phenomena caused by chemical incompatibility reactions between explosive and contact material could lead to an increase of the rate of binder degradation, stabilizer depletion, heat and gas production and weight loss. Furthermore, the sensitivity of the explosive can be increased. On the other hand, chemical reactions of the contact material can also be initiated, such as post curing and decomposition of binders and corrosion processes in container materials [4].

The experience-based rules regarding contact materials are as follows:

\footnotetext{
1) Military Technical Institute (VTI), Ratka Resanovića 1, 11132 Belgrade, SERBIA

Correspondence to: Mirjana Dimić; e-mail: mirjanadimicjevtic@gmail.com
} 
Inorganic contact materials: Neutral and slightly acidic inorganic compounds are usually compatible, whereas strong acids and strong oxidizers are often incompatible and strong alkalis are generally incompatible with explosives. Furthermore, commonly used metals and alloys are compatible with explosives.

Organic contact materials: Most polymers are compatible with explosives. Glues and varnishes sometimes give rise to incompatibility, in particular when their curing is caused by chemical reactions rather than by solvent evaporation [5-7]. Here, amine- and polyamide hardeners in epoxy-based glues and isocyanates in polyurethane products are often responsible for incompatibility with explosives. Incompatibilities are sometimes also found with acrylate and methacrylate glues and silicone paints.

Regarding explosives, it was found that less stable energetic materials such as primary explosives and aliphatic nitrate esters are generally more susceptible towards incompatibilities than the more stable high explosives [6].

Thus, there are some additional incompatibilities which are specific or more distinctive for the individual explosive classes:

Propellants based on aliphatic nitrate esters, in particular if they contain nitroglycerine, are often incompatible also with nitrates and halogenides of alkaline metals, bitumen varnishes and black powder.

Some azides are strongly incompatible with non-ferrous heavy metals such as copper and thus, instable and dangerous copper azides are formed.

Pyrotechnics are usually compatible with inert and nitrocellulose-based binders but often incompatible with energetic polymer binders [1].

Analysis of numerous compatibility tests shows that contact materials which are found to be incompatible with one class of organic explosives very often are also incompatible with the other classes [8].

The most reliable way to investigate compatibility is to use a variety of techniques to investigate chemical and physical reactions and to perform aging experiments as close to storage conditions as possible. In most cases this is very timeconsuming. In practice, one expects reliable results from a compatibility investigation in a short time. To do this, some tests based on accelerated aging at higher temperatures are available, measuring gas evolution (vacuum stability test), heat effects ((HFC) and (DSC)), weight loss (TGA) or stabilizer loss [2].

Standard, which describes the testing and assessment of chemical compatibility, is STANAG 4147 [9]. According to this standard, the purpose of a compatibility test is: to provide evidence that a material may be used in an item of ammunition without detriment to the safety or reliability of an explosive with which it is in contact or proximity.

This standard, STANAG 4147, describes the following tests and procedures:

- Vacuum stability (Test 1)

- Heat flow calorimetry (Test 2)

- Thermogravimetric analysis (Test 3)

- Differential scanning calorimetry (Test 4)

- Chemical analysis after aging (Test 5)

For a long time, the vacuum stability test was the most applied chemical method. Moreover, criteria of compatibility for vacuum stability test were considered as one of the valid criteria. That is correct until other four methods for compatibility are not applied.

All spontaneous chemical and physical processes are associated with heat effects. Monitoring the flow of heat was used to study the compatibility of explosive and polymer materials by using heat flow calorimeter [2, 10-12]. This method is widely accepted in laboratories engaged in the study of polymer compatibility and explosive materials [1].

Thermal analytical techniques such as DSC, TGA and (DTA), use small samples and mass measurement results are obtained in a short period of time [13-15]. However, these methods are suitable for testing explosives and pyrotechnic compositions. On the other hand, a small mass of sample may be a drawback, due to samples nonhomogeneity. A study of the compatibility of thermal methods, e.g. DSC method, is based on monitoring changes in the melting temperature, or when it comes to two polymer materials, glass transition temperature, as well as the kinetic parameters of the activation energy [16].

For the evaluation of the test results, different approaches are in use, such as 'absolute' incompatibility $\left(Q_{r}=M-M_{\text {calc }}\right)$ and 'relative' incompatibility $\left(D=M / M_{\text {calc }}\right)$. Quantity $M$ is a specific property (e.g. heat release, evolved gas volume, stabilizer depletion) as measured for the mixture, and $M_{\text {calc }}$ the same property calculated for the mixture by linear combining the measured values of isolated explosive and contact material. Quantity $M$ itself can be used as the third criterion ('stability of the mixture') considering that, if two materials are regarded as compatible, their mixture has to be chemically stable as well and therefore must fulfill the stability test requirements of the respective explosive.

\section{Experimental part}

\section{Material}

Two samples of propellants and two of polymer materials were selected for this experimental:

- Double base propellant, designated as NGB-051,

- Single base propellant, designated as NC-028,

- Polyamide 12 (Nylon 12) and

- Polymethylmethacrylate (PMMA).

\section{Preparation of samples}

Single base propellant has a small rectangular form (approximately $2 \mathrm{~mm} \times 2 \mathrm{~mm}$ ) and it was used in original shape. On the other hand, a sample of double base propellant was chopped into small pieces, to the same dimensions (approximately $2 \mathrm{~mm} \times 2 \mathrm{~mm}$ ).

Examination samples of both polymers were raw materials and they were used in original shape (dimensions of granule are nearly $2 \mathrm{~mm} \times 2 \mathrm{~mm}$ ).

\section{Method of vacuum stability test}

Tests were carried out on the device for vacuum stability test, Stabil 20, OZM Research, in accordance with STANAG 4147 (Procedure B, test 1) heating the sample of double base propellant NGB-051, polymeric materials and their mixture for 96 hours at $90^{\circ} \mathrm{C}$. For single base propellant $\mathrm{NC}-28$ an experiment was carried out at the temperature of $100^{\circ} \mathrm{C}$, in accordance to the SORS 9374/13 standard [17]. The method is based on the principle of monitoring, i.e. determining the volume of released gases, which are developed above samples in a closed system under vacuum.

\section{Microcalorimetry method}

The tests were performed on heat flow calorimeter TAM III, TA Instruments. Test samples made of propellants, polymer materials and mixtures were heated for 168 hours at 
$85^{\circ} \mathrm{C}$ (STANAG 4147, test 2). The released heat, over time, for a mixture of propellants and polymeric material, is compared with reference value, which represents the sum of a heat released when these materials are heated separately.

\section{The method of differential scanning calorimetry}

Determination of thermal characterization was carried out in the temperature range from $100^{\circ} \mathrm{C}$ to $300^{\circ} \mathrm{C}$ at heat rate of $2^{\circ} \mathrm{C} / \mathrm{min}$ in the DSC Q 20, TA Instruments (STANAG 4147, test 4). Comparing the peak maximum decomposition of propellants with peak maximum decomposition of mixture (propellant and polymeric material) allows the discussion of compatibility.

\section{Methods of chemical analysis after aging}

Methods of chemical analysis are conducted in accordance with STANAG 4147 (test 5), specifying the content of the stabilizer, after aging for 14 days at $80^{\circ} \mathrm{C}$, samples and samples of propellants mixtures with polymeric materials. Aging was conducted in a thermal block Julius Peters, and determination of the stabilizer was performed on Waters 1525 liquid chromatography.

\section{The test results and analysis of results}

\section{Method of vacuum stability test}

The results of the evolved gas volumes of separate samples, their mixtures and the results of criteria of compatibility, $V_{R}$, are shown in Table 1 .

The evolved gas volumes, on the standard pressure and temperature, are calculated according to equation (1):

$$
V=\left(V_{c}+V_{t}-\sum \frac{m_{i}}{\rho_{i}}\right) \cdot\left(\frac{p_{2} \cdot 273}{273+t_{2}}-\frac{p_{1} \cdot 273}{273+t_{1}}\right) \cdot \frac{1}{1,013}
$$

Where:

$V$ - the evolved gas volume, $\mathrm{cm}^{3}$

$V_{c}$ - the volume of transducer, $\mathrm{cm}^{3}$

$V_{t}$ - the volume of glass test tubes, $\mathrm{cm}^{3}$

$m_{i}$ - mass of all examined samples, $\mathrm{g}$

$\rho_{i}$ - density of all examined samples, $\mathrm{g} / \mathrm{cm}^{3}$

$p_{1}$ - pressure at the beginning of the experiment, bar

$p_{2}$ - pressure at the end of the experiment, bar

$t_{1}$ - temperature at the beginning of the experiment, ${ }^{\circ} \mathrm{C}$

$t_{2}$ - temperature at the end of the experiment, ${ }^{\circ} \mathrm{C}$.

Knowing the values of the evolved gas volumes for the all analyzed samples from equation (1), a criterion of compatibility is calculated according to equation (2):

$$
V_{R}=M-(E+S)
$$

Where:

$V_{R}$ - the evolved gas volume effected as a reaction of the components in a mixture;

$M$ - the evolved gas volume of the mixture of energetic and polymer materials, mixed in a mass ratio $(2.5+$ 2.5) $\mathrm{g}$;

$E \quad$ - the evolved gas volume of the energetic material, mass of the samples $2.5 \mathrm{~g}$;

$S$ - the evolved gas volume of the examination material (polymer material), mass of the samples $2.5 \mathrm{~g}$;

Where:

$V_{R}<5 \mathrm{~cm}^{3}$ - the mixture is considered to be compatible,
$V_{R}>5 \mathrm{~cm}^{3}$ - the mixture is considered to be incompatible,

$V_{R}=5 \mathrm{~cm}^{3}$ - it is necessary to apply other methods of determining the compatibility.

\begin{tabular}{|c|c|c|c|c|}
\hline \multirow{2}{*}{ Sample } & \multicolumn{3}{|c|}{ The evolved gas volume, $\mathrm{cm}^{3}$} & \multirow{2}{*}{$V_{R}, \mathrm{~cm}^{3}$} \\
\hline & $M$ & $E$ & $S$ & \\
\hline NGB-051/Nylon 12 & 15.977 & & & \multirow{3}{*}{12.612} \\
\hline NGB-051 & & 2.864 & & \\
\hline Nylon 12 & & & 0.501 & \\
\hline NGB-051/PMMA & 1.705 & & & \multirow{3}{*}{1.776} \\
\hline NGB-051 & & 2.864 & & \\
\hline PMMA & & & 0.617 & \\
\hline NC-28/Nylon $12^{(*)}$ & 0.993 & & & \multirow{3}{*}{0.760} \\
\hline $\mathrm{NC}-28^{(*)}$ & & 1.086 & & \\
\hline Nylon $12^{(*)}$ & & & 0.677 & \\
\hline NC-28/PMMA ${ }^{(*)}$ & 1.126 & & & \multirow{3}{*}{0.514} \\
\hline $\mathrm{NC}-28^{(*)}$ & & 1.086 & & \\
\hline $\mathrm{PMMA}^{(*)}$ & & & 0.554 & \\
\hline
\end{tabular}

Table 1. Results of the vacuum stability test

The results obtained using the method of vacuum stability test show that double base propellant NGB-051 is incompatible with nylon 12 and compatible with PMMA.

It is approved that double base propellant NGB-051 is chemically stable, using the same method. For the mass of 2.5 $\mathrm{g}$ of this propellant the evolved gas volume is $2.8 \mathrm{~cm}^{3}$, calculating on a volume per gram $1.12 \mathrm{~cm}^{3} / \mathrm{g}$. According to the criteria of chemical stability the evolved gas volume of samples should be less than $1.2 \mathrm{~cm}^{3} / \mathrm{g}$ in order to be considered as chemically stable.

On the other hand, the results for the single base propellant and both types of polymer materials show that they fulfill compatibility criteria.

\section{Microcalorimetry method}

Results of the individual measurements were performed for the release of heat, or heat flow of the double and single base propellants, polymeric materials and mixtures thereof, as well as the calculation of the theoretical curves, Figures 1-4.

By comparing the theoretical and experimental curves of the heat flow a good agreement is observed with the mixtures NC-28/nylon 12, NC-28/PMMA and NGB-051/PMMA, while a significant disagreement is evident at mixture NGB051/nylon 12 .

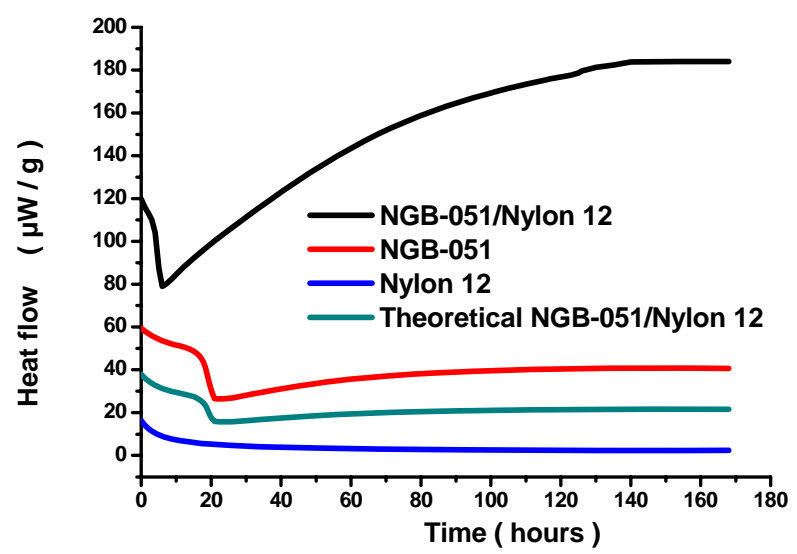

Figure 1. Heat flow curves of components and mixtures NGB-051/Nylon 12 


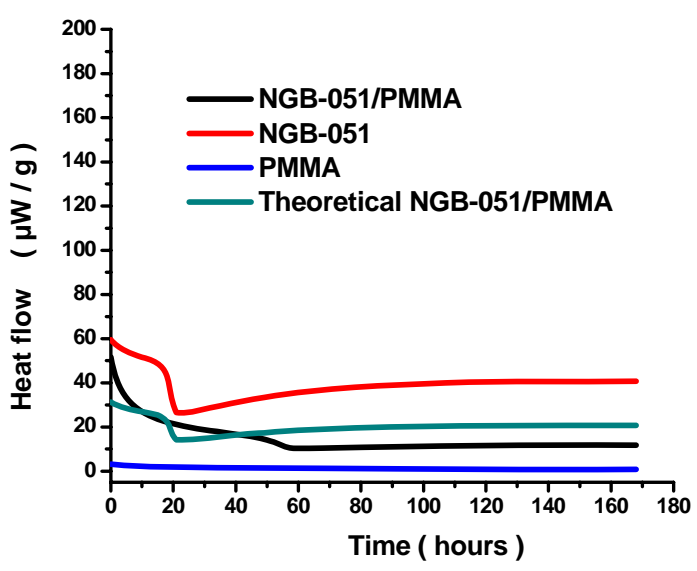

Figure 2. Heat flow curves of components and mixtures NGB-051/PMMA

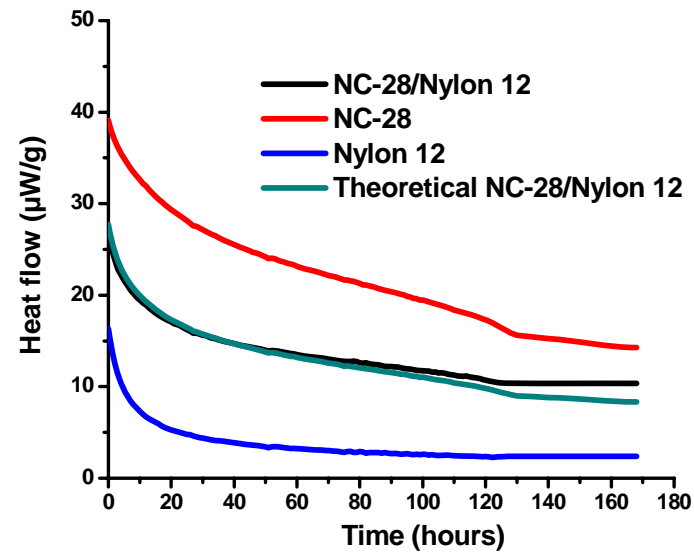

Figure 3. Heat flow curves of components and mixtures NC-28/Nylon12

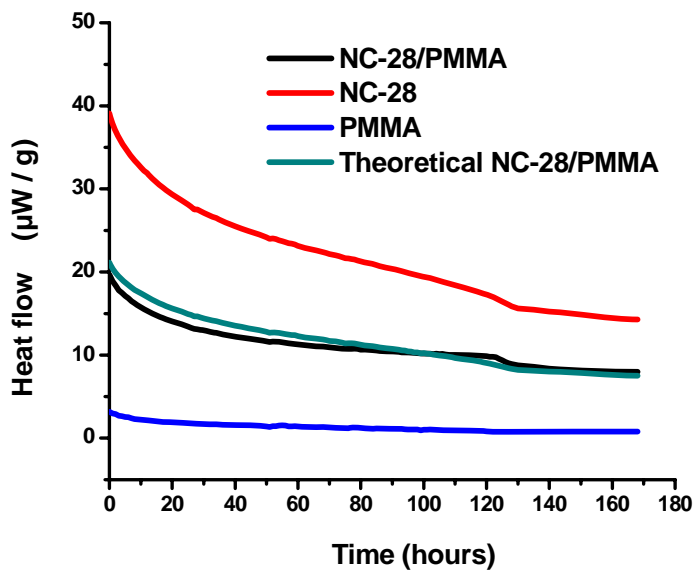

Figure 4. Heat flow curves of components and mixtures NC-28/PMMA

Based on the results of measurements the energy released per unit mass for energy materials, polymeric materials and mixtures thereof was determined. Based on these results the relative compatibility (D), was calculated given with eq.(3)

$$
D=\frac{2 \times M}{E+S}
$$

where:

$M \quad$ - heat generation of the mixture, $\mathrm{J} / \mathrm{g}$;

$E \quad$ - heat generation of the propellant, $\mathrm{J} / \mathrm{g}$;

$S \quad$ - heat generation of the polymer, $\mathrm{J} / \mathrm{g}$.

When:

$D<2$ - the mixture is considered to be compatible;

$D>3 \quad$ - the mixture is considered to be incompatible;
$2<D<3$ - the mixture is considered "moderately" incompatible (it is necessary to apply other methods of determining the compatibility).

Table 2 shows the calculated values of the energy for the propellants NGB-051, NC-28 and its mixtures with polymer materials, and based on that calculated the relative compatibility D.

Table 2. Values of energy released and the relative compatibility

\begin{tabular}{|c|c|c|}
\hline Sample & Energy released, $\mathrm{J} / \mathrm{g}$ & $\begin{array}{c}\text { Relative compat. } \\
\text { D }\end{array}$ \\
\hline NGB-051/Nylon 12 & 91.16 & \multirow{3}{*}{7.11} \\
\hline NGB-051 & 23.47 & \\
\hline Nylon 12 & 2.17 & \\
\hline NGB-051/PMMA & 8.88 & \multirow{3}{*}{0.73} \\
\hline NGB-051 & 23.47 & \\
\hline PMMA & 0.77 & \\
\hline NC-28/Nylon 12 & 8.01 & \multirow{3}{*}{1.05} \\
\hline NC-28 & 13.11 & \\
\hline Nylon 12 & 2.17 & \\
\hline NC-28/PMMA & 6.66 & \multirow{3}{*}{0.96} \\
\hline NC-28 & 13.11 & \\
\hline PMMA & 0.77 & \\
\hline
\end{tabular}

Applying the criterion of the relative compatibility it can be concluded that the propellant NGB-051 is incompatible with the polymeric material of nylon 12 (D>3), and is compatible with PMMA $(\mathrm{D}<2)$.

On the other hand, single base propellant NC-28 is compatible with both polymer materials (nylon 12 and PMMA) according to the criteria of the relative compatibility $(\mathrm{D}<2)$.

Samples of the propellants are stable according to the STANAG 4582 criteria by using microcalorimetry method. The heat released by the samples is not over $201 \mu \mathrm{W} / \mathrm{g}$ during 168 hours on the temperature of $85^{\circ} \mathrm{C}$. According to this result it can be said that incompatibility of NGB- 051 and nylon 12 is not the reason of powder instability. Moreover, it is caused by interaction of energetic and polymer materials.

These results can be accepted, because microcalorimetry method is the most confidential method for compatibility for gun powders and rocket propellants with test materials [2].

\section{The method of differential scanning calorimetry}

The DSC thermogram can show endothermic, exothermic peak and the temperature of peak maximum. On the DSC thermogram of polymer material only peak of melting point is present, i.e. endothermic peak. There is no exothermic peak, i.e. peak which represents the process of decomposition.

On the DSC thermogram of double and single base propellants and mixture of propellants and polymer materials there exist only exothermic peak of decomposition.

The temperature of peak maximum was determined and the maximum difference in peak temperatures $\Delta \mathrm{T}$ was calculated by using Thermal Stability Kinetics Analysis for single and double base propellant and for mixture of propellants with polymer materials. Presence of test material causes the degradation of energetic material and that causes a decrease of the maximum peak of decomposition.

For:

$\Delta T<4^{\circ} \mathrm{C} \quad-$ the mixture is considered to be compatible;

$4^{\circ} \mathrm{C}<\Delta T<20^{\circ} \mathrm{C}$ - the mixture is considered "moderately" incompatible (it is necessary to apply other methods of determining the compatibility);

$\Delta T>20^{\circ} \mathrm{C}$ the mixture is considered to be incompatible 
The values of maximum peak $\left(\mathrm{T}_{\max }\right)$, temperature shift $(\Delta T)$ and compatibility assessment are shown in Table 3.

Table 3. Results of the DSC method

\begin{tabular}{|c|c|c|c||}
\hline Sample & $\begin{array}{c}\text { Point of } \\
\text { exothermic peak, } \\
T_{\max },{ }^{\circ} \mathrm{C}\end{array}$ & $\Delta T,{ }^{\circ} \mathrm{C}$ & Compat. assessment \\
\hline \hline NGB-051 & 190.95 & & \\
\hline NGB-051/Nylon 12 & 190.23 & 0.72 & Compatible \\
\hline NGB-051/PMMA & 191.8 & -0.85 & Compatible \\
\hline NC -28 & 192.70 & & \\
\hline NC-28/Nylon 12 & 192.95 & -0.25 & Compatible \\
\hline NC-28/PMMA & 193.87 & -1.17 & Compatible \\
\hline
\end{tabular}

In Table 3 the negative value of $\Delta T$ for the following mixtures NGB-051/PMMA, NC-28/Nylon 12 and for NC28/PMMA can be seen. The explanation for this result is not the decrease of maximum peak of decomposition of mixture as it is expected, but it is the opposite.

According to the criteria and the corresponding results, tested samples of mixture (propellants and polymer materials) are considered compatible.

\section{Methods of chemical analysis after aging}

Results of content of stabilizer of aging and non-aging samples of single and double base propellant and mixtures of propellants and polymer materials are shown in Table 4.

Table 4. Results of the chemical analysis after aging

\begin{tabular}{|c|c|c|}
\hline Sample & $\begin{array}{c}\text { Content of } \\
\text { stabilizer, mass. } \\
\%\end{array}$ & $\begin{array}{l}\text { The compatibility } \\
\text { factor, } K\end{array}$ \\
\hline NGB-051, aging, (A) & 1.58 & \multirow{3}{*}{1.35} \\
\hline NGB-051, non aging, (C) & 0.87 & \\
\hline NGB-051/ Nylon 12, (B) & 0.62 & \\
\hline NGB-051, aging, (A) & 1.58 & \multirow{3}{*}{0.63} \\
\hline NGB-051, non aging, (C) & 0.87 & \\
\hline NGB-051/PMMA, (B) & 1.13 & \\
\hline NC-28, aging, (A) & 1.26 & \multirow{3}{*}{1.09} \\
\hline NC-28, non aging, $(\mathrm{C})$ & 0.50 & \\
\hline NC-28/ Nylon 12, (B) & 0.43 & \\
\hline NC-28, aging, (A) & 1.26 & \multirow{3}{*}{1.00} \\
\hline NC-28, non aging, (C) & 0.50 & \\
\hline NC-28/PMMA, (B) & 0.50 & \\
\hline
\end{tabular}

For calculating the compatibility factor $(K)$ according to this method, we use equation (4):

$$
K=\frac{A-B}{A-C}
$$

where:

$A$ - content of stabilizer in a non-aging sample of double base propellant, mass. $\%$;

$B$ - content of stabilizer in a sample of propellant which is in a contact with polymer materials after heating, mass. \%;

$C$ - content of stabilizer in an aging sample of double base propellant, mass. $\%$.

When the compatibility factor is less than $1.5, K \leq 1.5$, the energetic materials are compatible with contact material.

It can be concluded that double base propellant NGB-051 and single base propellant $\mathrm{NC}-28$ are compatible with polymer materials by using the methods of chemical analysis after aging, according to the results.

The value of content of stabilizer is a little higher for the mixtures: NGB-051/PMMA and NC-28/PMMA than it is in an aging powder, table 4 . The explanation for this result: PMMA was melt; the extraction and the determined of content of stabilizer were not so easy and according to this, the value of content of stabilizer is increased.

\section{Conclusion}

Four different methods were used for determining the compatibility of single and double base propellant and polymer materials (nylon 12 and PMMA) according to STANAG 4147.

The results show that single base propellant $\mathrm{NC}-28$ is compatible with both polymer materials according to all four different methods that were used.

Double base propellant NGB-051 is incompatible with nylon 12 and compatible with PMMA when using microcalorimetry method and method of vacuum stability test.

On the other hand, double base propellant NGB-051 is compatible with both polymer materials using the other two methods, the differential scanning calorimetry and chemical analysis after aging. According to the results these two methods cannot be used, for sure, for giving the opinions about compatibility of double base propellant and polymer materials.

Reason lies in the facts that:

- double base propellants are not homogeneous samples and the method of differential scanning calorimetry uses a very small mass of examination samples (approximately 1-2 $\mathrm{mg}$ ) and all of that may affect the result.

- At the elevated temperature, according to the methods of chemical analysis after aging, the agglutination of the sample of the polymer material with the double base propellant is formed. That leads to the inaccuracies in the determination of the content of stabilizers, due to the impossibility of total separation of the propellant of the polymeric material.

Given the differences obtained by multiple testing methods, it is necessary to be very careful in making a final decision on compatibility. This only testifies to the fact that the chemical compatibility is the complex parameter and it is always necessary to conduct several different methods, and to interpret the results carefully.

\section{References}

[1] VOGELSANGER B.: Chemical Stability, Compatibility and Shelf Life of Explosives, Chimia, 2004, Vol.58, No.6, pp.401-408.

[2] Recommendations on the Transport of Dangerous Goods, Manual of Tests and Criteria, third revised edition, United Nations, New York and Geneva, 1999, pp. 117-119, 124-125.

[3] KLERK,W., MEER,N.V., EERLINGH,R.: Microcalorimetric study applied to the comparison of compatibility tests (VST and IST) of polymers and propellants, Thermochimica Acta, 1995, Vol.269-270, pp.231-243.

[4] BOHN,M.A.: The use of Kinetic Equations to Evaluate the Ageing Behavior of Energetic Materials-Possible Problems, $11^{\text {th }}$ Symp. on Chemical Problems connected with the Stability of Explosives, Bastad, Sweden 1998; M.A. Bohn, Mö glichkeiten zur Voraussage der Nutzungsdauer von Treibmitteln mit Stabilisatorabnahme, Molmassenabnahme und anderen Messgrö flen, Forum "Explosivstoffe", WI-WEB, Germany, 2000.

[5] STANKOVIĆ,M., DIMIĆ,M., BLAGOJEVIĆ,M., PETROVIĆ,S., MIJIN,D.: Compatibility examination of explosive and polymer materials by thermal methods, Scientific Technical Review, ISSN 1820-0206, 2003, Vol.LIII, No.1, pp.25-29.

[6] STUCKI,H.: Prüfung der Verträglichkeit von Explosivstoffen mit diversen Materialien, Armasuisse Report Nr. TA-6-SIG Sti$22.10 / 2334,1980$. 
[7] WILKER,S.: Verträglichkeitsuntersuchungen organischer Explosivstoffe mit Kon-taktstoffen 1995-2000, WIWEB Germany, Report Nr. 710/24117/00, 2000.

[8] HAHMA,A., HIHKIÖ,M., PIHLAJA,K., KANTOLAHTI,E.: Microcalorimetric Measurements of Compatibilities of Paints with Selected Energetic Materials, Internat. Symp. on Energetic Materials Technology, American Defense Preparedness Association,1995.

[9] STANAG 4147 (Edition 2), Chemical Compability of Ammunition Componentes with Explosives (Non-Nuclear Application), June 2001.

[10] ELMQVIST,C.J., LAGERQKVIST,P.E., SVENSSON,L.G.: Stability and compatibility testing using microcalorimetric method, J. Hazaardous Materials, 1983, pp.281-290

[11] SVENSSON,L.G., FORSGREN,C.K., BACKMAN,P.O.: Microcalorimetric methods in shelf life technology, Symposium on Compatibility of Plastics and Other Materials with Explosives, Propellants and Pyrotechnics ,1988, pp.132-137.

[12] STANKOVIĆ,M., ANTIĆ,G., BLAGOJEVIĆ,M., PETROVIĆ,S.: Microcalorimetric Compatibility Testing of the Constituents of Combustible Materials and Casting Composite Explosives, Journal of Thermal Analysis, 1998, 52, pp.581-585
[13] STAUB,H.M., REICH,H.U.: Loss Prevention by Thermal Compatibility Tests, AD-POO4 456/O/HDM, 1982, pp.271-280.

[14] LIU,Z.R.: The Characteristic Temperature Method to Estimate Kinetic Parameters From DTA Curves and to Evaluate the Compatibility of Explosives, Propellants, Explos., Pyrotech., 1986, Vol.11, No.1, pp.1015.

[15] De KLERK,W.P.: Thermal Analysis of Some Propellants and Explosives with DSC and TG/DTA, AD-A320 678/6/HDM, 1996.

[16] BOYKIN,T.L., MOORE,R.B.: The role of specific interactions and transreactions on the compatibility of polyester ionomers with poly(ethylene terephthalate) and nylon 6,6, Polymer Engineering \& Science, 1998, Vol.38, No.10, pp.1658-65.

[17] SORS 9374/13: Baruti i raketna goriva-METODA TEST VAKUUM STABILNOSTI, Beograd, 2013.

\title{
Analiza hemijske kompatibilnosti baruta i polimernih materijala primenom različitih metoda ispitivanja
}

\begin{abstract}
U ovom radu su prikazani rezultati ispitivanja hemijske kompatibilnosti jednobaznog i dvobaznog baruta (NGB-051 i NC-28) sa dva različita tipa polimernih materijala (Poliamid 12 i Polimetilmetakrilat) korišćenjem različitih metoda ispitivanja. Ispitivanja su izvršena sledećim metodama: metodom mikrokalorimetrije, metodom diferencijalne skenirajuće kalorimetrije, metodom hemijske analize posle starenje i metodom vakuum-test stabilnosti. Određene su krive toplotnog protoka za barute i polimerne materijale, njihove mešavine, kao i teoretske krive. Izračunata je oslobođena energija i određene vrednosti relativne i apsolutne kompatibilnosti. Izvršena je analiza egzotermnih pikova dekompozicije baruta i njihovih mešavina sa polimernim materijalima i izračunata razlika u temperaturama maksimuma pikova. Određen je sadržaj stabilizatora u uzorcima nestarenih i starenih baruta i starenih mešavina baruta sa polimernim materijalima. Određene su vrednosti zapremine oslobođenih gasova za barute i polimerne materijale kao i za njihove mešavine. Izračunate su vrednosti apsolutne kompatibilnosti. Na osnovu svih prikazanih rezultata izvršena je ocena kompatibilnosti.
\end{abstract}

Ključne reči: jednobazni barut, dvobazni barut, polimerni materijali, kompatibilnost, metoda ispitivanjja, mikrokalorimetrija, diferencijalna skanirajuća kalorimetrija, starenje, analiza stabilnosti.

\section{Анализ химической совместимости пропеллентов и полимерных материалов с использованием различных методов испытаний}

\begin{abstract}
В настоящем документе представлены результаты испытаний на химическую совместимость однобазовых и двухбазовых пропеллентов (NGB-051 и NC-28) с двумя различными типами полимерных материалов (полиамид 12 и полиметилметакрилат) с использованием различных методов испытаний. Испытания проводились с использованием следующих методов: метода микрокалориметрии, метода дифференциальной сканирующей калориметрии, метода химического анализа после старения и метода испытания на устойчивость к вакууму. Определены кривые теплового потока для пропеллентов и полимерных материалов, для их смесей и теоретических кривых. Вычисляются освобождённая энергия и определённые значения относительной и абсолютной совместимостей. Был проведён анализ экзотермических пиков разложения пропеллентов и их смесей с полимерными материалами и рассчитана разница в максимальных пиковых температурах. Содержание стабилизатора определяли в образцах необработанных и стареющих пропеллентов и стареющих смесей пропеллентов с полимерными материалами. Определены значения объёма выделяемых газов для пропеллентов и полимерных материалов, а также и для их смесей. Вычисляются значения абсолютной совместимости. Оценка совместимости была выполнена на основе всех отображаемых результатов.
\end{abstract}

Ключевые слова: однобазовый пропеллент, двухбазовый пропеллент, полимерные материалы, совместимость, метод испытаний, микрокалориметрия, дифференциальная сканирующая калориметрия, старение, анализ стабильности. 


\title{
Analyse de la compatibilité chimique de poudre et des matériaux polymères par différentes méthodes d'essais
}

\begin{abstract}
Ce papier présente les résultats des recherches sur la compatibilité chimique de poudre monobasique et bibasique (NGB-051 et NC 28) avec deux types des matériaux polymères (Polyamide 12 et Polyméthyle métacrylate ) en utilisant différentes méthodes d'essais. Les essais ont été effectués à l'aide des méthodes suivantes : microcalorimétrie, calorimétrie différentielle scannante, analyse chimique après le vieillissement et par le vacuum test de stabilité. On a déterminé les courbes du courant thermique pour les poudres et les matériaux polymères, leurs mélanges ainsi que les courbes théoriques. On a calculé l'énergie libérée et on a déterminé les valeurs de la compatibilité relative et absolue. On a analysé les pointes exothermiques de la décomposition des poudres et de leurs mélanges avec les matériaux polymères et on a calculé la différence dans les températures du maximum des pointes. On a déterminé le contenu de stabilisateur dans les échantillons des poudres vieillies / non vieillies ainsi que les mélanges des poudres vieillies avec les matériaux polymères. Les valeurs du volume chez les gaz libérés pour les poudres, les matériaux polymères et pour leurs mélanges ont été déterminées aussi. Les valeurs de la compatibilité absolue ont été calculées. L'évaluation de la compatibilité a été faite à la base de tous les résultats présentés.
\end{abstract}

Mots clés: poudre monobasique, poudre bibasique, matériaux polymères, compatibilité, méthode d'essai, microcalorimétrie, calorimétrie différentielle scannante, vieillissement, analyse de stabilité. 